\title{
Protective effect and economic impact of insecticide application methods on barley
}

\author{
Alfred Stoetzer( ${ }^{(1)}$, Jackson Kawakami(2), Alberto Luiz Marsaro Júnior ${ }^{(3)}$, \\ Douglas Lau ${ }^{(3)}$, Paulo Roberto Valle da Silva Pereira ${ }^{(3)}$ e Noemir Antoniazzi ${ }^{(1)}$
}

(1)Fundação Agrária de Pesquisa Agropecuária, Praça Nova Pátria, s/no, Entre Rios, CEP 85139-400 Guarapuava, PR, Brazil.
E-mail: alfred@agraria.com.br, noemir@agraria.com.br (2)Universidade Estadual do Centro-Oeste, Rua Simeão Camargo Varela de Sá, no3,
CEP 85040-080 Guarapuava, PR, Brazil. E-mail: jkawa13@hotmail.com ${ }^{(3)}$ Embrapa Trigo, Rodovia BR-285, Km 294, Caixa Postal 451,
CEP 99001-970 Passo Fundo, RS, Brazil. E-mail: alberto.marsaro@embrapa.br, douglas.lau@embrapa.br, paulo.pereira@embrapa.br

Abstract - The objective of this work was to evaluate the protective effect of different forms of insecticide application on the transmission of yellow dwarf disease in barley cultivars, as well as to determine the production costs and the net profit of these managements. The experiments were carried out during 2011 and 2012 growing seasons, using the following managements at main plots: T1, seed treatment with insecticide (ST) + insecticide on shoots at 15-day interval; T2, just ST; T3, insecticide applied on shoots, when aphid control level (CL) was reached; T4, without insecticide; and T5, ST + insecticide on shoots when CL was reached. Different barley cultivars - BRS Cauê, BRS Brau and MN 6021 - were arranged in the subplots. Insecticides lambda cyhalothrin (pyrethroid) and thiamethoxam (neonicotinoid) were used. There were differences on yellow dwarf disease index in both seasons for the different treatments, while damage to grain yield was influenced by year and aphid population. Production costs and net profit were different among treatments. Seed treatment with insecticide is sufficient to reduce the transmission of yellow dwarf disease in years with low aphid population pressure, while in years with larger populations, the application of insecticide on shoots is also required.

Index terms: Hordeum vulgare, Metopolophium dirhodum, Rhopalosiphum padi, seed treatment, yellow dwarf disease.

\section{Efeito protetor e impacto econômico de métodos de aplicação de inseticidas em cevada}

Resumo - O objetivo deste trabalho foi avaliar o efeito protetor de diferentes formas de aplicação de inseticida sobre a transmissão do nanismo amarelo em cultivares de cevada, bem como determinar os custos de produção e o lucro líquido destes manejos. Os experimentos foram realizados durante as safras 2011 e 2012, tendo-se utilizado os seguintes manejos nas parcelas principais: T1, tratamento de sementes com inseticida (TS) + inseticida na parte aérea aplicado quinzenalmente; T2, apenas TS; T3, inseticida aplicado à parte aérea, quando foi atingido o nível de controle de afídeos (NC); T4, sem inseticida; e T5, TS + inseticida na parte aérea, quando o NC foi atingido. As subparcelas foram constituídas de diferentes cultivares de cevada: BRS Cauê, BRS Brau e MN 6021. Foram utilizados os inseticidas lambda-cialotrina (piretroide) e thiametoxam (neonicotinoide). Houve diferenças no índice de doença do nanismo amarelo em ambas as safras para os diferentes manejos, enquanto o dano ao rendimento de grãos foi influenciado pelo ano e pela população de afídeos. Os custos de produção e lucro líquido diferiram entre os tratamentos. Constatou-se que o tratamento de sementes com inseticida é suficiente para reduzir a epidemia do nanismo-amarelo em anos com baixa pressão populacional de afídeos; porém, em anos com maiores populações, a aplicação de inseticida à parte aérea também se torna necessária.

Termos para indexação: Hordeum vulgare, Metopolophium dirhodum, Rhopalosiphum padi, tratamento de sementes, nanismo amarelo.

\section{Introduction}

Barley (Hordeum vulgare Linnaeus, 1753) and other winter cereals are important in the succession of summer crops. In 2012, Brazil produced 265.025 tons of barley (Instituto Brasileiro de Geografia e Estatística, 2012). Aphids are the major pest of winter cereals and are the most important virus vectors, transmitting about $30 \%$ of all plant viruses know to date (Brault et al., 2010). Around 100 aphids per day per plant are estimated to cause about $1 \%$ damage to grain yield of wheat cultivars currently in use in Brazil (Savaris et al., 2013). Considering the current aphid population levels in winter cereals in Brazil, the greatest damage is indirect, arising from the transmission of yellow dwarf disease (YDD) (Kennedy \& Connery, 2005). 
This disease is caused by Luteovirus and Polerovirus species (family Luteoviridae), specially Barley yellow $d$ warf virus (BYDV)-PAV the predominant species (Mar et al., 2013; Parizoto et al., 2013). Nowadays, aphid species frequently found in Southern Brazil are Rhopalosiphum padi (Linnaeus, 1758) and Sitobion avenae (Fabricius, 1794), both efficient vectors of BYDV-PAV (Parizoto et al., 2013). The higher the $R$. padi incidence on winter cereals, the lower the grain yield, if no control is used (Fabre et al., 2003).

There are many studies on wheat for the following variables: cultivar response to damage caused by R. padi (Silva et al., 2004; Savaris et al., 2013); yield response to different locations, aphid abundance, and BYDV incidence (Hesler et al., 2005); R. padi feeding duration and infestation densities (Rosa-Gomes et al., 2008); determination of parents in wheat breeding program to obtain tolerant genotypes to BYDV (Barbieri et al., 2001); and efficiency of insecticides to reduce aphid population (Silva et al., 2004), among others.

As to barley, although there are studies on the use of insecticide (Kennedy \& Connery, 2005; Brault et al., 2010), or other products (Hamada \& Jonsson, 2013), and on management to control YDD, there are few studies on the quantification of damage caused by YDD to barley cultivars, and on the efficiency and economic viability of insecticide management.

The objective of this work was to evaluate the protective effect of various forms of insecticide application on the transmission of YDD in barley cultivars, as well as to determine the production costs and the net profit of these managements.

\section{Materials and Methods}

The experiment was conducted in field conditions at Fundação Agrária de Pesquisa Agropecuária (Fapa), Guarapuava, Paraná, Brazil (at $25^{\circ} 34^{\prime} \mathrm{S}, 51^{\circ} 29^{\prime} \mathrm{W}$, 1,132 m altitude) in 2011 and 2012 (from July to November). The experiment was settled on July 6, 2011, in a randomized block design, with a split-plot arrangement and four replicates. The main plots received the insecticide applications, and the subplots were composed by different barley cultivars. The treatments were: $\mathrm{T} 1$, seed treatment with insecticide (ST), plus insecticide applied on shoots at 15-day interval; T2, just ST; T3, insecticide applied on shoots, when the control level (CL) was reached, according to the scale described in Reunião Nacional de Pesquisa de Cevada (2011), by which the CL is 10 aphids per tiller; and T4, without insecticide application. Each plot was subdivided into two subplots which contained the following cultivars: BRS Cauê and BRS Brau. In 2012, the trial was settled on July 3 , in addition to the treatments and cultivars above described. Treatment T5 was included in the main plot (ST + insecticide on shoots, when CL was hit), and the barley cultivar MN 6021 in the subplot. Products used to control aphids were: $7.5 \mathrm{~g}$ a.i. lambda cyhalothrin (pyrethroid) $+42 \mathrm{~g}$ a.i. thiamethoxam (neonicotinoid) per $100 \mathrm{~kg}$ seed for ST, and $5.3 \mathrm{~g}$ a.i. lambda cyhalothrin $+7.05 \mathrm{~g}$ i.a. thiamethoxam per ha for shoot control.

Seed were treated with $30 \mathrm{~g}$ a.i. Difenoconazole (triazol) per $100 \mathrm{~kg}$ seed. For ST, one day before sowing, insecticide and fungicide were diluted in polymer $0.5 \%$, Policlaro, (Basf, Pinhais, PR) and applied on seed, which were then shaken in a plastic bag to coat them evenly with the chemical pesticides. The aerial application of insecticides was made by a $\mathrm{CO}_{2}$-propelled sprayer, using XR 110.02 nozzles with $200 \mathrm{~L} \mathrm{ha}^{-1}$ flow rate. In 2011, T3 received one insecticide application on shoots, at 73 days after emergence (DAE), corresponding to the stadium 10 of Feeks and Large scale (Large, 1954), when CL was reached. In 2012, T3 and T5 received one insecticide application each, on shoots, respectively at 59 DAE (stage 9 Feeks and Large scale), and 62 DAE (stage 10 Feeks and Large scale). T1, received seven and six insecticide applications, in 2011 and 2012, respectively.

The subplot consisted of 11 rows spaced at $0.17 \mathrm{~m}$ with $6 \mathrm{~m}$ length, from which 11 rows of $5 \mathrm{~m}$ length as useful area, totaling $9.35 \mathrm{~m}^{2}$ in 2011, and 9 rows and $5 \mathrm{~m}$ length as useful area, totaling $7.65 \mathrm{~m}^{2}$ in 2012. Sowing was done with a plot seeder model 3 (Semina, Caxias do Sul, RS, Brazil), using a density of 280 viable seeds per $\mathrm{m}^{2}$. Fertilization and nitrogen in coverage, as well as other cultural practices, followed the technical recommendations for barley crop (Reunião Nacional de Pesquisa de Cevada, 2011). Harvest was done mechanically with a plot harvester model Classic (Wintersteiger, Ried, Austria). In both seasons, for each treatment, the following evaluations were done: disease index (DI); grain yield and thousand seed weight (TSW), both adjusted to $13 \%$ moisture; test weight (TW) that refers to the average weight of a 
cereal as measured in $\mathrm{kg} \mathrm{hl}^{-1}$; assortment of commercial barley and protein percentage. The assortment of barley was carried out through an assortment machine with mesh sieves of $2.8,2.5$, and $2.2 \mathrm{~mm}$, through which a $0.1 \mathrm{~kg}$ grain sample was passed. Grain percentage retained in the sieves of $2.8 \mathrm{~mm}$ and $2.5 \mathrm{~mm}$ was considered the first-class barley grain; second-class barley grain was retained in the sieve of $2.2 \mathrm{~mm}$; and third-class barley grain passed through sieve $2.2 \mathrm{~mm}$ (European Brewery Convention, 1998). Protein concentration was determined by a grain analyzer device with near infrared reflectance spectroscopy Infratec 1241, (Foss, Toowoomba, Australia) (Long et al., 2008).

A visual assessment of viral disease symptoms was made at stage 11.2 of the Feeks and Large scale by assigning grades to 30 consecutive plants per plot, starting at a random selected plant from the center of the plot, and using the following adapted scale from Qualset (1983): score 0, plants without visible symptoms; score 1, mild yellowing and discoloration on leaves, in plants with normal stature, and vigorous appearance; score 2, moderate leave yellowing, no sign of dwarfism or reduced tillers, unaffected plant strength; score 3, moderate to severe leaf yellowing and mild yellowing at the tips, slight stunting, plant strength moderately affected; score 4 , most leaves with severe yellowing and moderate redness at the tips, small spikes, moderate dwarfism, strongly affected plant strength, reduced tillering; score 5, complete yellowing of all leaves and intense redness, reduction of the number of tillers, little or no spike, stunting, considerable sterility, forced maturation, or drying of the leaves.

To calculate the disease index (DI) for each plot, the McKinney (1923) formula DI $=\Sigma[(\mathrm{fv}) \times 100 /(\mathrm{nx})]$ was used, in which: $\mathrm{f}$ is the number of plants with the same score; $\mathrm{v}$ is the observed score; $\mathrm{n}$ is the total number of evaluated plants; and $\mathrm{x}$ is the maximum score of the scale.

In both years, aphid sampling was conducted in the experimental area (approximately 10,000 $\mathrm{m}^{2}$ ). Winged aphids were weekly collected, preferably on the same day of the week and time, through 8 yellow water-pan traps $(40.5 \times 28.0 \times 15.0 \mathrm{~cm})$ containing water, formaldehyde $(0.5 \%)$, and detergent, according to aphid sampling method described by Resende et al. (2007). Traps were randomly distributed in the monitoring area. Trap contents were collected with the aid of a 60 mesh sieve $(0.250 \mathrm{~mm})$, and in the laboratory, winged aphids were separated from other collected insects and identified to species level. For each year, curves were constructed with total aphid (aphids per trap per week), in order to observe population variation over the study time (July to November).

To estimate the economic effects of different insecticide managements, the average data of the variables grain yield, TW, commercial classification, and percentage of protein of each treatment were used, plus the cost of inputs and cost of agricultural operations in each year, varying the value of the insecticides used in each treatment. Input prices and agricultural operations followed the prevailing prices and costs of each season, obtained by the technical department of the Cooperative Agrária Agroindustrial, located in Guarapuava, Paraná, Brazil. The sale price considered the average price at harvest (December) for each year. The rule and procedure of receiving, sorting and commercialization of the winter crop were adopted according to the Cooperative Agrária Agroindustrial for premium or discount payment due to grain quality of each treatment. The cost of shoot-application of insecticide was taken into account because it is understood that these applications could not be done with herbicide, or fungicide applications, whose costs were also considered in this study, but separately from insecticide. The price paid for barley varied depending on the assortment because the first-class grains pay $5.4 \%$ above the base price, while the values of second and third-class barley grains are equivalent to 79 and $10 \%$ of the base price, respectively. Shipping and receiving/drying discount varied as function of grain yield.

The agronomic data were subjected to analysis of variance and the means were compared by Tukey test, at $5 \%$ probability, using the statistical package SAS. Variance homogeneity of the data was verified by Box-Cox test (Box \& Cox, 1964). Thus, in 2011 the variables third-class grains and DI were transformed to $\log \mathrm{x}$, and in 2012 these same variables were transformed into $\log \mathrm{x}+1$ and $\mathrm{x}^{0,5}$, respectively, and the yield was transformed to $1 / \mathrm{x}^{0,5}$.

\section{Results and Discussion}

In 2011, 638 aphids were collected, from which 121 were not aphid pests of winter cereals. The predominant

Pesq. agropec. bras., Brasília, v.49, n.3, p.153-162, mar. 2014 DOI: $10.1590 / \mathrm{S} 0100-204 X 2014000300001$ 
species was $R$. padi, with $66.7 \%$ occurrence, followed by Metopolophium dirhodum (Walker, 1849) with $23.0 \%$. In 2012, 3,960 aphids were collected, among these, from which 82 were not aphid pests of winter. The predominant specie was $R$. padi, with a total of $83.3 \%$ occurrence, followed by $M$. dirhodum, with $10.7 \%$, and $S$. avenae with $3.8 \%$. The other species had a frequency less than $1 \%$. Rhopalosiphum padi and $M$. dirhodum species were the most frequent and, possibly, the most important aphids which influence YDD epidemics, which was also observed in studies in South Brazil (Parizoto et al., 2013), where 92.6\% BYDV were transmitted by $R$. padi. Knowing the predominant species in each region is extremely important, since aphid species have different capacity of virus transmission. This was shown by Parizoto et al. (2013), in an experiment by which virus was transmitted more efficiently by $R$. padi followed by $S$. avenae. Considering the total population of aphid pests of winter cereals, the population in 2012 was 7.5 times higher than in 2011 and, possibly, these differences resulted from the ones in weather conditions between years, mainly the amount of precipitation during the season (Figure 1), which was also observed in studies by Schuber et al. (2009). In 2011, there was a low aphid population in the early development of barley, occurring a slight increase in population from 63 DAE, covering the booting period, which chronologically corresponds to the end of September and early October. This largest population extended until 84 DAE, when the biggest population peak of this season (11.5 aphids per trap) occurred. After this period, aphid population decreased; however, it increased again in the late stage of grain filling (November). In 2012, at the early development of barley, aphid population was low. At the end of tillering, aphid population began to increase, reaching the biggest population peak at 70 DAE (94 aphids per trap), comprising the flowering stage. In this season, aphid population remained high until barley physiological maturity. Until 35 DAE, aphid population was low and similar for the two years. Weather conditions preceding the sampling period probably affected the initial aphid population because, at this period - June and July - more intense rainfalls were observed. This result corroborates the findings of Schuber et al. (2009), who reported that aphid population has an inverse correlation with rainfall in Paraná state, Brazil.
For none of the variables, in both seasons (Table 1 and Table 2), significant interactions between the insecticides managements and cultivars were observed; however, as the focus of this work was the handling of insecticides and interaction between managements and cultivars, there were only addressed data concerning the different managements.

As there was variation in the levels of aphid population, there was also variation in the incidence of viruses symptoms in different years. In 2011, with the lowest aphid population, the largest DI occurred in the control $(1.50 \%)$, differing from the other treatments, which did not differ statistically (Table 1). Even with the use of ST and 15-day interval application of insecticide on shoots, virus symptoms still occurred, indicating that the intensive use of insecticide was not able to prevent virus transmission. In 2012, the largest DI occurred in the control $(7.44 \%)$, and the treatment with the use of ST plus 15-day interval application of insecticide on shoots (T1) had the lowest DI (1.56\%) (Table 1). Higher disease values were observed in 2012 $(4.36 \%)$ compared to $2011(0.63 \%)$, which is associated with larger aphid populations in 2012 (Figure 1).

In relation to grain yield in 2011, the treatments did not differ statistically (Table 1). Therefore, in 2011, the low values of DI were not able to affect yield. In 2012, T1 with application of insecticides on seed and shoots had the highest grain yield $\left(3,112 \mathrm{~kg} \mathrm{ha}^{-1}\right)$, differing only from the control (T4), which produced 2,627 $\mathrm{kg} \mathrm{ha}^{-1}$. In 2012, there was a higher DI, thus affecting yield. These results can be compared to those of Kennedy \& Connery (2005), who observed a reduction of barley grain yield due to YDD. This reduction was 0.36 to $1.1 \mathrm{Mg} \mathrm{ha}^{-1}$, for plots with low and high virus infestations, respectively. Bisnieks et al. (2005) also noted a decrease in oats productivity due to YDD. The results indicate that the use of some form of insecticide is required to decrease the DI values in a year with low aphid populations, as in 2011; however, no effect was observed on the production in the present research. In years with high aphid population, such as 2012, in addition to ST use, insecticide applications on shoots with 15-day interval are necessary to decrease symptoms caused by virus with significant effect on yield. This was also observed by other authors, who found that ST with insecticides prevented the initial attack of aphids on wheat, and that the insecticide application to shoots also decreased aphid population, 

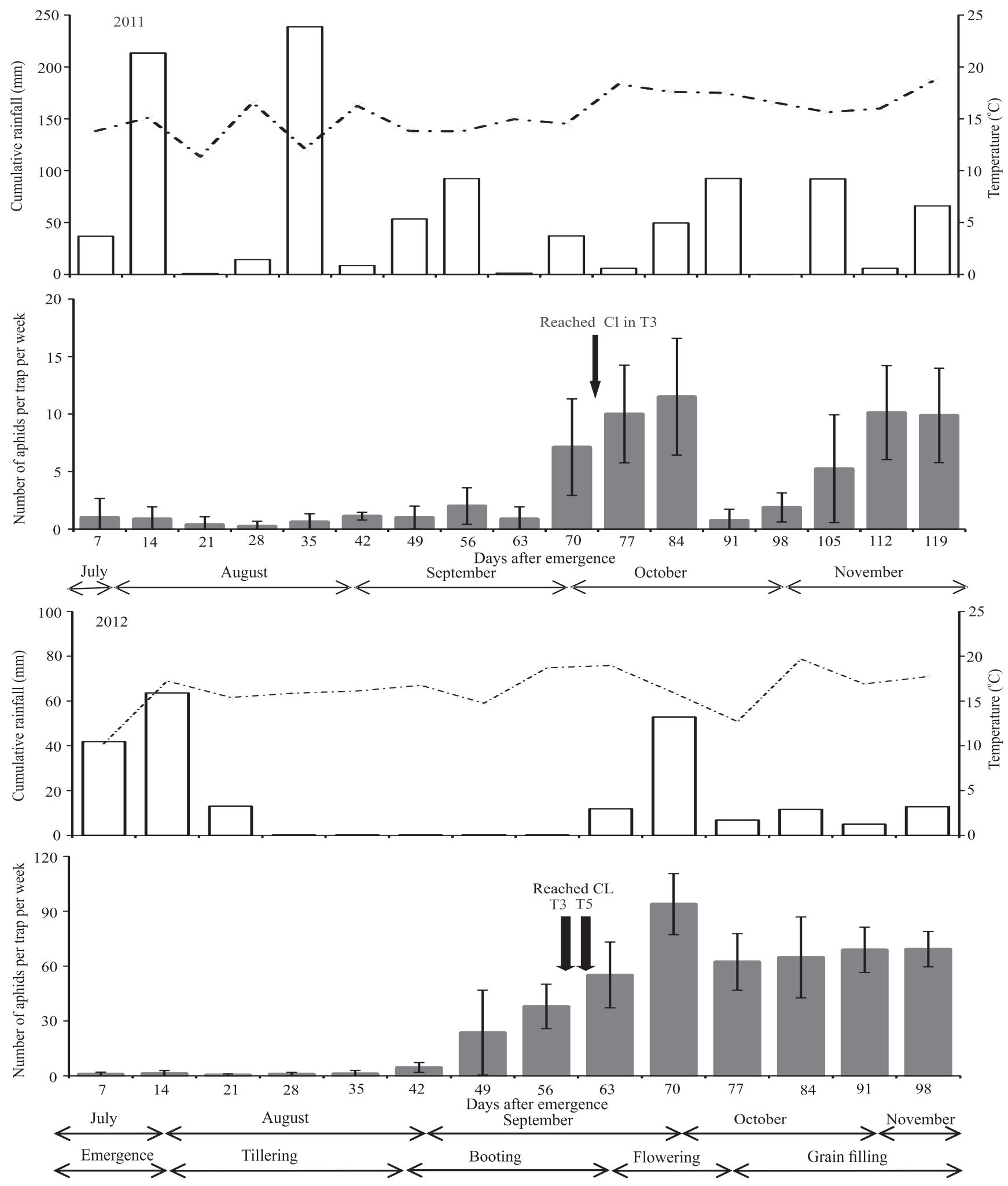

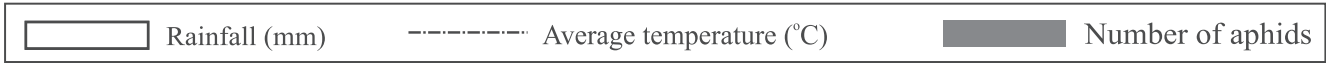

Figure 1. Number of aphids per trap per week, accumulated precipitation, and average temperature for the period from July to November 2011 and 2012. CL, control level; T3, insecticide applied on shoots, when CL was reached, according to the scale described by Reunião Nacional de Pesquisa de Cevada (2011). Bars correspond to standard deviation. $\mathrm{N}=8$. 
thus proving the importance of insecticides for aphid control and for YDD reduction (Silva et al., 2004). Kennedy \& Connery (2005) observed losses in barley grain yield from 10.6 to $11.3 \%$, due to the nonapplication of insecticide on shoots, and these losses were related to the presence of aphids (S. avenae) and symptoms of YDD. In 2012, there was no observed benefit to grain yield, which could be provided by the use of only ST with insecticide; these results differ from those of other authors, who conducted experiments with different managements of insecticides, and who founded that treatments with ST often resulted in plants with higher yields (Silva et al., 2004). The treatment only with ST did not differ from the control for barley yield.

For both years, there were no statistical differences between the treatments for TSW (Table 1), which were probably associated with low values of DI; however, Freeman et al. (2003) reported that infection with B/ CYDV may result in a reduction of TSW. In other studies with barley, a reduction was observed in TSW ranging from 3.2 to $14.9 \%$ between plants inoculated with BYDV-PAV and healthy plants (Edwards et al., 2001) and, for wheat, the same inoculation resulted in decrease in TSW between 16.9 and 38.4\% (Lanzarini et al., 2007). The differences between the present work and other studies, related to results for the variable

Table 1. Disease index (DI), grain yield, thousand seed weight (TSW), and test weight (TW) in barley with different chemical insecticide managements in 2011 and 2012 growing seasons ${ }^{(1)}$.

\begin{tabular}{lcccc}
\hline Treatment & $\begin{array}{c}\text { DI } \\
(\%)\end{array}$ & $\begin{array}{c}\text { Yield } \\
\left(\mathrm{kg} \mathrm{ha}^{-1}\right)\end{array}$ & $\begin{array}{c}\text { TSW } \\
(\mathrm{g})\end{array}$ & $\begin{array}{c}\text { TW } \\
\left(\mathrm{kg} \mathrm{hl}^{-1}\right)\end{array}$ \\
\hline & \multicolumn{4}{c}{2011} \\
ST + insecticide on shoots (T1) & $0.17 \mathrm{~b}$ & 6,453 & 48.1 & 68.6 \\
Only ST (T2) & $0.42 \mathrm{~b}$ & 6,568 & 47.8 & 69.1 \\
Insecticide on shoots - CL (T3) & $0.42 \mathrm{~b}$ & 6,363 & 48.0 & 68.6 \\
Control (T4) & $1.50 \mathrm{a}$ & 6,346 & 48.2 & 68.9 \\
\hline Mean & 0.63 & 6,422 & 48.0 & 68.8 \\
CV (\%) & 62.3 & 6.64 & 2.61 & 1.10 \\
\hline & \multicolumn{5}{c}{2012} \\
ST + insecticide on shoots (T1) & $1.56 \mathrm{c}$ & $3,112 \mathrm{a}$ & 44.4 & 67.2 \\
Only ST (T2) & $4.11 \mathrm{~b}$ & $2,907 \mathrm{ab}$ & 44.9 & 67.1 \\
Inseticide on shoots - CL (T3) & $4.56 \mathrm{~b}$ & $2,814 \mathrm{ab}$ & 44.4 & 66.7 \\
Control (T4) & $7.44 \mathrm{a}$ & $2,627 \mathrm{~b}$ & 44.3 & 66.1 \\
ST + insecticide on shoots - CL (T5) & $4.11 \mathrm{~b}$ & $2,992 \mathrm{ab}$ & 44.6 & 67.1 \\
\hline Mean & 4.36 & 2,890 & 44.5 & 66.8 \\
CV (\%) & 39.45 & 10.8 & 3.79 & 2.30 \\
\hline
\end{tabular}

${ }^{(1)}$ Means followed by equal letters, in the columns, do not differ, by Tukey's test, at 5\% probability. CL, control level according to Reunião Nacional de Pesquisa de Cevada (2011).
TSW, are probably due to a higher incidence and severity of YDD found by the authors, since those works were conducted under controlled conditions and high viruliferous aphid population, which drastically affected TSW.

There were no differences between treatments for TW in both years. Kennedy \& Connery (2005) reported a reduction of yield and quality of the final product of cereals such as TW and TSW, according to YDD infection; however Bisnieks et al. (2005) did not observe differences for TSW and TW due to the presence of YDD in oats.

For both years, there was no difference in the percentage of first, second and third classes of barley grains among the managements of insecticide (Table 2). These results differ from those obtained by Edwards et al. (2001), who observed a reduction from 11.9 to $38.9 \%$ between barley plants infected with BYDV-PAV, as well as healthy plants when they evaluated the percentage of barley grains retained on a $2.38 \times 19.05 \mathrm{~mm}$ sieve, while there was an increase from 12.6 to $401 \%$ for the percentage of seeds that have passed through a sieve $1.98 \times 19.05 \mathrm{~mm}$.

No insecticides management resulted in statistical differences for the percentage of protein in 2011 and 2012 (Table 2). However, studies conducted

Table 2. Commercial assortment (first, second and third class) and percentage of protein in barley grains under different chemical insecticide managements in 2011 and 2012 growing seasons ${ }^{(1)}$.

\begin{tabular}{lcccc}
\hline Treatment & $\begin{array}{c}\text { First } \\
\text { class (\%) }\end{array}$ & $\begin{array}{c}\text { Second } \\
\text { class (\%) }\end{array}$ & $\begin{array}{c}\text { Third } \\
\text { class (\%) }\end{array}$ & $\begin{array}{c}\text { Protein } \\
(\%)\end{array}$ \\
\hline & \multicolumn{5}{c}{2011} \\
ST + insecticide on shoots (T1) & 96.9 & 2.5 & 0.6 & 11.5 \\
Only ST (T2) & 96.4 & 2.7 & 0.9 & 11.3 \\
Insecticide on shoots CL (T3) & 96.5 & 2.8 & 0.7 & 11.4 \\
Control (T4) & 96.7 & 2.5 & 0.8 & 11.5 \\
\hline Mean & 96.6 & 2.6 & 0.8 & 11.4 \\
CV (\%) & 1.20 & 34.47 & 39.02 & 3.18 \\
\hline & \multicolumn{5}{c}{2012} \\
ST + insecticide on shoots (T1) & 90.9 & 6.8 & 2.3 & 12.4 \\
Only ST (T2) & 91.4 & 6.5 & 2.1 & 12.3 \\
Inseticida on shoots CL (T3) & 91.5 & 6.3 & 2.2 & 12.5 \\
Control (T4) & 88.1 & 8.8 & 3.0 & 12.4 \\
ST + insecticide on shoots CL (T5) & 91.4 & 6.3 & 2.3 & 12.5 \\
\hline Mean & 90.7 & 7.0 & 2.4 & 12.4 \\
CV (\%) & 4.82 & 47.32 & 32.31 & 5.19 \\
\hline
\end{tabular}

${ }^{(1)}$ Means followed by equal letters, in the columns, do not differ, by Tukey's test, at 5\% probability. CL, control level according to Reunião Nacional de Pesquisa de Cevada (2011). 
by Edwards et al. (2001) in barley plants inoculated with BYDV-PAV showed that infected plants had an increase of grain protein content, which ranged from 4.6 to $17.5 \%$, depending on the cultivar and year.

Considering the financial results of barley in 2011, monetary differences occurred among treatments depending on the application of insecticides (Table 3). The largest expense on the use of insecticide was observed for T1, which included ST and seven applications on shoots, with a total cost of R $\$ 189.18 \mathrm{ha}^{-1}$, followed by treatment using only the ST (T2), which presented a cost of R $\$ 99.93$ ha $^{-1}$. The treatment with the highest final revenue per area was $\mathrm{T} 2$, followed by T4. For the conditions of the year 2011, the ST and the control treatment without insecticide application showed the best return; however it is important to note that there was a lower aphid population in 2011, and there was no statistical difference between treatments for yield. This same advantage was cited by Royer et al. (2005), who mentioned that the ST with insecticide, as imidacloprid for instance, has certain economic and environmental qualities, such as low utilization rates (low doses per target), low exposure to the applicator and the prevention of cultures to virus. In 2011, among all the costs of each treatment, the cost of insecticide (product + application) was equivalent to $13.5 \%$ of total expenditures in $\mathrm{T} 1,6 \%$ in $\mathrm{T} 2$, and $1 \%$ in $\mathrm{T} 3$. This indicates that even insecticides being considered

Table 3. Financial statement between different treatments analyzed in barley during the 2011 growing season ${ }^{(1)}$.

\begin{tabular}{|c|c|c|c|c|}
\hline \multirow[t]{2}{*}{ Variable } & \multicolumn{4}{|c|}{ Financial statement } \\
\hline & ST + insecticide on shoots (T1) & Only ST (T2) & Insecticide on shoots - CL (T3) & Control (T4) \\
\hline \multicolumn{5}{|l|}{ Yield per class } \\
\hline First class $\left(\mathrm{kg} \mathrm{ha}^{-1}\right)$ & 6,253 & 6,332 & 6,140 & 6,137 \\
\hline Second class $\left(\mathrm{kg} \mathrm{ha}^{-1}\right)$ & 161 & 177 & 178 & 159 \\
\hline Third class $\left(\mathrm{kg} \mathrm{ha}^{-1}\right)$ & 39 & 59 & 45 & 51 \\
\hline Price per class & First class & Second class & Third class & \\
\hline Percentage of price ${ }^{(2)}$ & 105.4 & 79 & 10 & \\
\hline Price per class $\left(\mathrm{R} \$ \mathrm{Mg}^{-1}\right)$ & 544.45 & 408.08 & 51.66 & \\
\hline \multicolumn{5}{|l|}{ Gross revenues } \\
\hline First class $\left(\mathrm{kg} \mathrm{ha}^{-1}\right)$ & $\mathrm{R} \$ 3,404.45$ & $\mathrm{R} \$ 3,447.24$ & $\mathrm{R} \$ 3,343.11$ & $\mathrm{R} \$ 3,341.09$ \\
\hline Second class $\left(\mathrm{kg} \mathrm{ha}^{-1}\right)$ & $\mathrm{R} \$ 65.83$ & $\mathrm{R} \$ 72.37$ & $\mathrm{R} \$ 72.71$ & $\mathrm{R} \$ 64.74$ \\
\hline Third class $\left(\mathrm{kg} \mathrm{ha}^{-1}\right)$ & $\mathrm{R} \$ 2.00$ & $\mathrm{R} \$ 3.05$ & $\mathrm{R} \$ 2.30$ & $\mathrm{R} \$ 2.62$ \\
\hline Gross revenues $\left(\mathrm{R} \$ \mathrm{ha}^{-1}\right)$ & $\mathrm{R} \$ 3,472.28$ & $\mathrm{R} \$ 3,522.66$ & $\mathrm{R} \$ 3,418.12$ & $\mathrm{R} \$ 3,408.45$ \\
\hline \multicolumn{5}{|l|}{ Premium/discount ${ }^{(3)}$} \\
\hline $\mathrm{TW}\left(\mathrm{kg} \mathrm{hl}^{-1}\right)$ & 69 & 69 & 69 & 69 \\
\hline Premium (\%) & 4 & 4 & 4 & 4 \\
\hline Protein $(\%)$ & 11.5 & 11.3 & 11.4 & 11.5 \\
\hline Premium/discount (\%) & 0 & 0 & 0 & 0 \\
\hline \multicolumn{5}{|l|}{ Financial statement } \\
\hline (+)final gross revenue (ha) & $\mathrm{R} \$ 3,611.17$ & $\mathrm{R} \$ 3,663.57$ & $\mathrm{R} \$ 3,554.84$ & $\mathrm{R} \$ 3,544.79$ \\
\hline (-) production costs ${ }^{(4)}$ & $\mathrm{R} \$ 1,405.12$ & $\mathrm{R} \$ 1,405.12$ & $\mathrm{R} \$ 1,405.12$ & $\mathrm{R} \$ 1,405.12$ \\
\hline (-)freight $(\mathrm{R} \$)^{(5)}$ & $\mathrm{R} \$ 97.76$ & $\mathrm{R} \$ 99.51$ & $\mathrm{R} \$ 96.40$ & $\mathrm{R} \$ 96.14$ \\
\hline (-)reception/drying $(\mathrm{R} \$)^{(6)}$ & $\mathrm{R} \$ 94.79$ & $\mathrm{R} \$ 96.48$ & $\mathrm{R} \$ 93.47$ & $\mathrm{R} \$ 93.22$ \\
\hline$(-)$ variable costs $\left(R \$ \text { ha }^{-1}\right)^{(7)}$ & $\mathrm{R} \$ 189.18$ & $\mathrm{R} \$ 99.93$ & $\mathrm{R} \$ 12.75$ & $\mathrm{R} \$ 0.00$ \\
\hline -Aplication (equipment) & $\mathrm{R} \$ 55.65$ & $\mathrm{R} \$ 0.00$ & $\mathrm{R} \$ 7.95$ & $\mathrm{R} \$ 0.00$ \\
\hline -Insecticide on shoots $(7 \mathrm{x})$ & $\mathrm{R} \$ 33.60$ & $\mathrm{R} \$ 0.00$ & $\mathrm{R} \$ 0.00$ & $\mathrm{R} \$ 0.00$ \\
\hline -Insecticide on shoots $(1 \mathrm{x})$ & $\mathrm{R} \$ 0.00$ & $\mathrm{R} \$ 0.00$ & $\mathrm{R} \$ 4.80$ & $\mathrm{R} \$ 0.00$ \\
\hline -Insecticide seed treatment & $\mathrm{R} \$ 99.93$ & $\mathrm{R} \$ 99.93$ & $\mathrm{R} \$ 0.00$ & $\mathrm{R} \$ 0.00$ \\
\hline Final revenue (ha) & $\mathrm{R} \$ 1,824.32$ & $\mathrm{R} \$ 1,962.53$ & $\mathrm{R} \$ 1,947.10$ & $\mathrm{R} \$ 1,950.31$ \\
\hline \multicolumn{5}{|c|}{$\begin{array}{l}{ }^{(1)} \text { Average price paid to the producer for December } 2011\left(\mathrm{R} \$ 516.56 \mathrm{Mg}^{-1}\right) .{ }^{(2)} \text { Pondered price for each class of barley, according to standards of reception, } \\
\text { processing and commercialization of the Cooperativa Agrária Agroindustrial, which corresponds to the percentage paid for each assortment }(\mathrm{classification}) \\
\text { of the base price. }{ }^{(3)} \text { Premium or discounts to TW and protein, according to standards of reception, processing and commercialization of the Cooperativa } \\
\text { Agrária Agroindustrial. }{ }^{\left({ }^{4}\right)} \text { Average cost of production, considering the inputs and operations made in the experiment, referring to } 2011 .{ }^{(5)} \text { Freight, considering } \\
\text { a distance of } 100 \mathrm{~km} \text { at a cost of } \mathrm{R} \$ 15.15 \text { per Mg grain transported. }{ }^{(6)} \text { Value for the cost of receiving and drying barley, considering a cost of } \mathrm{R} \$ 14.69 \mathrm{per} \\
\mathrm{Mg} \text { grain delivered. }{ }^{(7)} \text { Variable production costs of each treatment, considering } \mathrm{R} \$ 96.00 \text { per liter of insecticide for aphid control on shoots, and } \mathrm{R} \$ 333.12 \\
\text { per liter of a standard insecticide for seed treatment. ST, Seed treatment. CL, control level according to Reunião Nacional de Pesquisa de Cevada }(2011) \text {. }\end{array}$} \\
\hline
\end{tabular}


inexpensive by many producers may increase the cost of production and, consequently, may reduce the final revenue. As for the financial results of barley in 2012 (Table 4), the average cost of production was $\mathrm{R} \$ 1,521.58 \mathrm{ha}^{-1}$. The treatment with the highest final revenue per area was T1, while the control (T4) had the lowest income. As the conditions in 2012 were different from those observed in 2011, with a higher aphid population, the use of insecticide provided a greater financial return, compared to the untreated control, and needed the use of ST and more insecticide applications on shoots to get the greatest financial return (Table 4). Although the use of ST + insecticide applied on shoots in 15-day interval (T1) had the highest cost for the use of insecticides (R\$ $168.61 \mathrm{ha}^{-1}$ ), the higher grain yield associated with the best assortment resulted in a greater final revenue. For 2012, the data showed the same trend of the study made by Stern \& Orloff (1991), who reported that, in some barley areas, two to three insecticide applications on shoots were necessary to control aphids because, at that situation, aphids were responsible for causing damage to barley yield, reducing TSW and the quality of grain, and increasing the costs of purchase and insecticide applications. Reports made in Idaho (USA) showed that less than $10 \%$ of barley areas are treated regularly

Table 4. Financial statement between different treatments analyzed in barley during the 2012 growing season ${ }^{(1)}$.

\begin{tabular}{|c|c|c|c|c|c|}
\hline \multirow[t]{2}{*}{ Variable } & \multicolumn{5}{|c|}{ Financial statement } \\
\hline & $\begin{array}{l}\text { ST + insecticide } \\
\text { on shoots (T1) }\end{array}$ & $\begin{array}{c}\text { Only } \\
\text { ST (T2) }\end{array}$ & $\begin{array}{c}\text { Insecticide on } \\
\text { shoots - CL (T3) }\end{array}$ & $\begin{array}{l}\text { Control } \\
\text { (T4) }\end{array}$ & $\begin{array}{l}\text { ST + Insecticide on } \\
\text { shoots - CL (T5) }\end{array}$ \\
\hline \multicolumn{6}{|l|}{ Yield per class } \\
\hline First class $\left(\mathrm{kg} \mathrm{ha}^{-1}\right)$ & 2,829 & 2,657 & 2,575 & 2,314 & 2,735 \\
\hline Second class $\left(\mathrm{kg} \mathrm{ha}^{-1}\right)$ & 212 & 189 & 177 & 231 & 188 \\
\hline Third class $\left(\mathrm{kg} \mathrm{ha}^{-1}\right)$ & 72 & 61 & 62 & 79 & 69 \\
\hline Price per class & First class & Second class & Third class & & \\
\hline Percentage of price ${ }^{(2)}$ & 105.4 & 79 & 10 & & \\
\hline Price per class $\left(\mathrm{R} \$ \mathrm{Mg}^{-1}\right)$ & 674.84 & 505.81 & 64.03 & & \\
\hline \multicolumn{6}{|l|}{ Gross revenues } \\
\hline First class $\left(\mathrm{kg} \mathrm{ha}^{-1}\right)$ & $\mathrm{R} \$ 1,909.01$ & $\mathrm{R} \$ 1,793.06$ & $\mathrm{R} \$ 1,737.60$ & $\mathrm{R} \$ 1,561.85$ & $\mathrm{R} \$ 1,845.49$ \\
\hline Second class $\left(\mathrm{kg} \mathrm{ha}^{-1}\right)$ & $\mathrm{R} \$ 107.04$ & $\mathrm{R} \$ 95.58$ & $\mathrm{R} \$ 89.67$ & $\mathrm{R} \$ 116.93$ & $\mathrm{R} \$ 95.34$ \\
\hline Third class $\left(\mathrm{kg} \mathrm{ha}^{-1}\right)$ & $\mathrm{R} \$ 4.58$ & $\mathrm{R} \$ 3.91$ & $\mathrm{R} \$ 3.96$ & $\mathrm{R} \$ 5.05$ & $\mathrm{R} \$ 4.41$ \\
\hline Gross revenues $\left(\mathrm{R} \$ \mathrm{ha}^{-1}\right)$ & $\mathrm{R} \$ 2,020.63$ & $\mathrm{R} \$ 1,892.55$ & $\mathrm{R} \$ 1,831.23$ & $\mathrm{R} \$ 1,683.83$ & $\mathrm{R} \$ 1,945.24$ \\
\hline \multicolumn{6}{|l|}{ Premium/discount ${ }^{(3)}$} \\
\hline $\mathrm{TW}\left(\mathrm{kg} \mathrm{hl}^{-1}\right)$ & 67 & 67 & 67 & 66 & 67 \\
\hline Premium (\%) & 2 & 2 & 2 & 1 & 2 \\
\hline Protein $(\%)$ & 12.4 & 12.3 & 12.5 & 12.4 & 12.5 \\
\hline Premium/discount (\%) & 0 & 0 & -1.3 & 0 & -1.3 \\
\hline \multicolumn{6}{|l|}{ Financial statement } \\
\hline$(+)$ final gross revenues $(\mathrm{ha})$ & $\mathrm{R} \$ 2,061.04$ & $\mathrm{R} \$ 1,930.40$ & $\mathrm{R} \$ 1,844.05$ & $\mathrm{R} \$ 1,700.67$ & $\mathrm{R} \$ 1,958.86$ \\
\hline$(-)$ production $\operatorname{costs}^{(4)}$ & $\mathrm{R} \$ 1,521.58$ & $\mathrm{R} \$ 1,521.58$ & $\mathrm{R} \$ 1,521.58$ & $\mathrm{R} \$ 1,521.58$ & $\mathrm{R} \$ 1,521.58$ \\
\hline$(-)$ freight $(\mathrm{R} \$)^{(5)}$ & $\mathrm{R} \$ 49.05$ & $\mathrm{R} \$ 45.81$ & $\mathrm{R} \$ 44.35$ & $\mathrm{R} \$ 41.40$ & $\mathrm{R} \$ 47.15$ \\
\hline$(-)$ reception/drying $(\mathrm{R} \$)^{(6)}$ & $\mathrm{R} \$ 57.04$ & $\mathrm{R} \$ 53.29$ & $\mathrm{R} \$ 51.58$ & $\mathrm{R} \$ 48.15$ & $\mathrm{R} \$ 54.84$ \\
\hline$(-)$ variable costs $\left(R \$ h^{-1}\right)^{(7)}$ & $\mathrm{R} \$ 168.61$ & $\mathrm{R} \$ 91.27$ & $\mathrm{R} \$ 12.89$ & $\mathrm{R} \$ 0.00$ & $\mathrm{R} \$ 104.16$ \\
\hline -Aplication (equipment) & $\mathrm{R} \$ 48.60$ & $\mathrm{R} \$ 0.00$ & $\mathrm{R} \$ 8.10$ & $\mathrm{R} \$ 0.00$ & $\mathrm{R} \$ 8.10$ \\
\hline -Insecticide on shoots $(6 \mathrm{x})$ & $\mathrm{R} \$ 28.74$ & $\mathrm{R} \$ 0.00$ & $\mathrm{R} \$ 0.00$ & $\mathrm{R} \$ 0.00$ & $\mathrm{R} \$ 0.00$ \\
\hline -Insecticide on shoots $(1 \mathrm{x})$ & $\mathrm{R} \$ 0.00$ & $\mathrm{R} \$ 0.00$ & $\mathrm{R} \$ 4.79$ & $\mathrm{R} \$ 0.00$ & $\mathrm{R} \$ 4.79$ \\
\hline -Insecticide seed treatment & $\mathrm{R} \$ 91.27$ & $\mathrm{R} \$ 91.27$ & $\mathrm{R} \$ 0.00$ & $\mathrm{R} \$ 0.00$ & $\mathrm{R} \$ 91.27$ \\
\hline Final revenues (ha) & $\mathrm{R} \$ 264.76$ & $\mathrm{R} \$ 218.45$ & $\mathrm{R} \$ 213.65$ & $\mathrm{R} \$ 89.53$ & $\mathrm{R} \$ 231.12$ \\
\hline
\end{tabular}


with insecticides, since $73 \%$ of the producers routinely monitor pests in crops, applying insecticides only when plagues struck the CLs, and always advocating integrated pest management (Olson et al., 2003). There was a significant decrease of income from all treatments in 2012 (Table 4) compared to 2011 (Table 3), fact explained by the prolonged drought period (Figure 1), which drastically reduced grain yield (Table 1).

\section{Conclusions}

1. Rhopalosiphum padi was the most frequent aphid species found.

2. Differences in weather conditions between years, as the amount of precipitation, affect total population of aphids.

3. The management with insecticides can be done for the culture as a whole, without taking into account the cultivar.

4. Seed treatment with insecticide is sufficient to reduce the transmission of viruses in years with low aphid population pressure, while in years with larger populations the application of insecticide on shoots is also required.

\section{References}

BARBIERI, R.L.; CARVALHO, F.I.F. de; BARBOSA NETO, J.F.; CAETANO, V. da R.; MARCHIORO, V.S.; AZEVEDO, R. de; LONRECETTI, C. Análise dialélica para tolerância ao vírus-do-nanismo-amarelo-da-cevada em cultivares brasileiras de trigo. Pesquisa Agropecuária Brasileira, v.36, p.131-135, 2001. DOI: 10.1590/S0100-204X2001000100016.

BISNIEKS, M.; PERSSON, T.; ECKERSTEN, H.; SIGVALD, R. The effects on yield and components of yield in oats infected with BYDV-PAV at different growth stages. Journal of Plant Diseases and Protection, v.112, p.521-528, 2005.

BOX, G.E.P.; COX, D.R. An analysis of transformations. Journal of the Royal Statistical Society, v.26, p.211-252, 1964.

BRAULT, V.; UZEST, M.; MONSION, B.; JACQUOT, E.; BLANC, S. Aphids as transport devices for plant viruses. Comptes Rendus Biologies, v.333, p.524-538, 2010. DOI: 10.1016/j. crvi.2010.04.001

EDWARDS, M.C.; FETCH, T.G.; SCHWARZ, P.B.; STEFFENSON, B.J. Effect of Barley yellow dwarf virus infection on yield and malting quality of barley. Plant Disease, v.85, p.202-207, 2001. DOI: 10.1094/PDIS.2001.85.2.202.

EUROPEAN BREWERY CONVENTION. Analytica-EBC: Grundwerk. Nürnberg: Carl, 1998.

FABRE, F.; DEDRYVER, C.A.; LETERRIER, J.L.; PLANTEGENEST, M. Aphid abundance on cereals in autumn predicts yield losses caused by Barley yellow dwarf virus. Phytopathology, v.93, p.1217-1222, 2003. DOI: 10.1094/ PHYTO.2003.93.10.1217.

FREEMAN, A.; HOLLAWAY, G.; BEDGGOOD, W.; AFTAB, M. Barley Yellow Dwarf Virus (BYDV) and Cereal Yellow Dwarf Virus (CYDV). Victoria: Department of Environment and Primary Industries, 2003.

HAMADA, A.M.; JONSSON, L.M.V. Thiamine treatments alleviate aphid infestations in barley and pea. Phytochemistry, v.94, p.135-141, 2013. DOI: 10.1016/j.phytochem.2013.05.012.

HESLER, L.S.; RIEDELL, W.E.; LANGHAM, M.A.C.; OSBORNE, S.L. Insect infestations, incidence of viral plant diseases, and yield of winter wheat in relation to planting date in the northern Great Plains. Journal of Economic Entomology, v.98, p.2020-2027, 2005. DOI: 10.1603/0022-0493-98.6.2020.

INSTITUTO BRASILEIRO DE GEOGRAFIA E ESTATÍSTICA. Produção agrícola municipal. 2012. Disponível em: <http:// www.ibge.gov.br/home/estatistica/economia/pam/2012/default. shtm>. Acesso em: 8 mar. 2014.

KENNEDY, T.F.; CONNERY, J. Grain yield reductions in spring barley due to barley yellow dwarf virus and aphid feeding. Irish Journal of Agricultural and Food Research, v.44, p.111-128, 2005.

LANZARINI, A.C.; SCHONS, J.; SALVADORI, J.R.; NIENOW, A.A.; NICOLINI-TEIXEIRA, F.; BINOTTO-MISSIURA, F.; DEUNER, E. Avaliação de danos causados pelo Barley yellow dwarf virus - PAV em cultivares de trigo no Brasil. Fitopatologia Brasileira, v.32, p.512-517, 2007. DOI: 10.1590/ S0100-41582007000600011.

LARGE, E.C. Growth stages in cereals - illustration of the Feekes scale. Plant Pathology, v.3, p.128-129, 1954. DOI: 10.1111/ j.1365-3059.1954.tb00716.x.

LONG, D.S.; ENGEL, R.E.; SIEMENS, M.C. Measuring grain protein concentration with in-line near infrared reflectance spectroscopy. Agronomy Journal, v.100, p.247-252, 2008. DOI: 10.2134/agrojn12007.0052.

MAR, T.B.; LAU, D.; SCHONS, J.; YAMAZAKI-LAU, E.; NHANI JUNIOR, A. Molecular identification based on coat protein sequences of the Barley yellow dwarf virus from Brazil. Scientia Agricola, v.70, p.428-434, 2013. DOI: 10.1590/ S0103-90162013000600008.

MCKINNEY, H.H. Influence of soil temperature and moisture on infection of wheat seedlings by Helminthosporium sativum. Journal of Agricultural Research, v.26, p.195-217, 1923.

OLSON, K.; DOWNEY, L.A.; RONDA, E.H. Idaho crop profiles: Barley. Idaho: University of Idaho, 2003. 6p.

PARIZOTO, G.; REBONATTO, A.; SCHONS, J.; LAU, D. Barley yellow dwarf virus-PAV in Brazil: seasonal fluctuation and biological characteristics. Tropical Plant Pathology, v.38, p.11-19, 2013. DOI: 10.1590/S1982-56762013000100002.

QUALSET, C.O. Evaluation and breeding methods for Barley yellow dwarf resistance. In: CUELLAR, E.; BURNETT, P.A. (Ed.). Barley yellow dwarf: a proceedings of the workshop. México: CIMMYT, 1983. p.72-80. 
RESENDE, A.L.S.; SILVA, E.E. da; GUERRA, J.G.M.; AGUIAR-MENEZES, E. de L. Amostragem de pulgões alados utilizando bandeja d'água e placa adesiva. Seropédica: Embrapa Agrobiologia, 2007. 4p. (Embrapa Agrobiologia. Circular técnica, 19).

REUNIÃO NACIONAL DE PESQUISA DE CEVADA, 28., 2011, Guarapuava. Indicações técnicas para a produção de cevada cervejeira nas safras 2011 e 2012. Passo Fundo: Embrapa Trigo, 2011. 100p. (Embrapa Trigo. Sistemas de produção, 6).

ROSA-GOMES, M.F.; SALVADORI, J.R.; SCHONS, J. Danos de Rhopalosiphum padi (L.) (Hemiptera: Aphididae) no trigo em função da duração e da densidade de infestação. Neotropical Entomology, v.37, p.577-581, 2008. DOI: 10.1590/ S1519-566X2008000500013.

ROYER, T.A.; GILES, K.L.; NYAMANZI, T.; HUNGER, R.M.; KRENZER, E.G.; ELLIOTT, N.C.; KINDLER, S.D.; PAYTON, M. Economic evaluation of the effects of planting date and application rate of imidacloprid for management of cereal aphids and Barley yellow dwarf in winter wheat. Journal of Economic Entomology, v.98, p.95-102, 2005. DOI: 10.1603/0022-0493-98.1.95.
SAVARIS, M.; LAMPERT, S.; SALVADORI, J.R.; LAU, D.; PEREIRA, P.R.V.S.; SMANIOTTO, M.A. Population growth and damage caused by Rhopalosiphum padi (L.) (Hemiptera, Aphididae) on different cultivars and phenological stages of wheat. Neotropical Entomology, v.42, p.539-543, 2013. DOI: 10.1007/ s13744-013-0158-9.

SCHUBER, J.M.; MONTEIRO, L.B.; POLTRONIERI, A.S.; CARVALHO, R.C.Z.; ZAWADNEACK, M.A.C. Population fluctuation and faunal indices of aphids (Hemiptera, Aphididae) in peach orchards in Araucaria, PR. Brazilian Journal of Biology, v.69, p.943-949, 2009. DOI: 10.1590/ S1519-69842009000400024.

SILVA, M.T.B. da; COSTA, E.C.; BALARDIN, R.S. Reação de cultivares e eficiência do controle químico de pulgões vetores do Barley yellow dwarf virus em trigo. Ciência Rural, v.34, p.1333-1340, 2004. DOI: 10.1590/S0103-84782004000500003.

STERN, V.M.; ORLOFF, S. Controlling Russian wheat aphid in California. California Agriculture, v.45, p.6-8, 1991. DOI: 10.3733/ca.v045n01p6.

Received on September 6, 2013 and accepted on February 25, 2014 